\title{
CAUSAL RELATIONSHIPS OF MORAL HAZARD AND ADVERSE SELECTION OF GHANAIAN PUBLIC-PRIVATE PARTNERSHIP (PPP) CONSTRUCTION PROJECTS
}

\author{
D Owusu-Manu, A Kukah, D Edwards, E Pärn, H El-Gohary, C Aigbavboa
}

\begin{abstract}
Purpose - The aim of this paper was to assess the causal relationship(s) between moral hazard and adverse selection of Public-Private-Partnership (PPP) construction projects. Structural Equation Modeling (SEM) was used to explore the causes and effects relationships between moral hazard and adverse selection problems in PPP construction projects in Ghana. The study produced a framework to predict, estimate and depict the complex causal relationships (i.e. the directionality) between moral hazard and adverse selection.
\end{abstract}

Design/Methodology/Approach - To test the proposed framework, a quantitative methodology was employed, in which, data were collected using research questionnaires that targeted a sample of two-hundred and eighty public-private-partnership (PPP) stakeholders in Ghana. A total of two hundred and ten useable questionnaires were retrieved representing a response rate of seventy-five percent.

Findings - The interrelationships between the eight causes and nine effects of moral hazard and adverse selection were established using the model. The tested framework showed the degree of association and isolation of the unobserved variables on the indicator factors. Confirmatory Factor Analysis (CFA) was used to evaluate the fit of items to latent constructs. Because the fit of each model was good and the item loadings were adequate, it was assumed that the indicators of the different variables factors were fitting. Furthermore, a diagnostic fit analysis was conducted using the robust maximum likelihood method to test the statistical significance of the parameter estimates.

Originality/Value - The research findings will serve as a guide for construction stakeholders in the PPP sector on the causes and effects of adverse selection and moral hazard, and how to mitigate these.

Practical Implications - This novel research is one of the few studies investigating the causal relationships between moral hazard and adverse selection of PPP construction projects. The research concluded with future studies that seek to validate the model developed in other countries and/ or other industries. 
Keywords - Moral Hazard, Adverse Selection, Structural Equation Modeling (SEM), Causal Relationships, Public-Private-Partnership (PPP).

\section{INTRODUCTION}

An immediate challenge that faces Public-Private Partnerships (PPPs) is the existence of informational asymmetries among the government (a principal) and the private firm (an agent) (Blanc-Brude, 2013). For this reason, information asymmetries must be factored during the design of any PPP contract (Ceric, 2011; De-Palma et al., 2009). Often and during the contract work, the agent is better informed than the principal on related ongoing activities and the actions of the private party that impact on these activities (Blanc-Brude, 2013). For example, the principal cannot observe or substantiate if the firm applies maximum effort required in the construction process (Loben, 2009). A moral hazard problem arises when the agent's action is not verifiable, or when the agent receives private information after the partnership has been commenced. Moral hazard should not pose a challenge or problem if both the principal and agent had the same objective functions. However, the misunderstanding about which action should be taken is the basis for agency costs (Loben, 2009; Blanc-Brude, 2013).

An adverse selection problem happens when the agent holds private information before the relationship begins. The principal can authenticate the agent's behaviour; however, the optimal decision which is the cost of this decision relies on the agent's type (which is considered to be private information related to the agent). Although the principal can be aware that the agent can be one of several possible types, they cannot identify the exact type without access to the agent (Loben, 2009). Moral hazard and adverse selection problems often do not exist in isolation (Yang and Yang, 2010). This is normally a result of the existence of synergies between stages of the venture, accounting for why different tasks are bundled in a distinct activity and delegated to a sole responsible agent firm (Biong, 2013). The effort that the agent firm exerts at the construction stage influences the circumstances it encounters at the operation stage. For example, exercising effort might enhance the chance of meeting a high demand for the service (as the infrastructure is more dependable) or, a reduced price of production (as the cost is an internal attribute of the project). As such, provision of effort by the agent is advantageous (Blanc-Brude, 2013).

Within extant literature, moral hazard and adverse selection research frontiers have been expanded and propagated by various authors (Monteiro, 2010; Wuyts et al., 2009; Blombäck and Axelsson, 2007). Biong (2013) investigated reputation and pricing effects on choosing subcontractors in asymmetric markets while, Monteiro (2009) explored risk management in agency relationships. According to Monteiro (2009), in the project's bidding phase, the tenderer does not know precisely the bidder's technical strength, level of management, service quality among others. The bidder is similarly unclear of the tender's financial capacity and business reputation. This can create both 
moral hazard and adverse selection problems. However, most authors examined moral hazard and adverse selection concentrating on procurement systems, supply chain management, outsourcing, and make-or-buy decisions (Ive and Chang, 2007; Yiu et al., 2002; Tedelis, 2002). For instance, Corvellec and Macheridis (2010) conducted a study on the impact of adverse selection on building performance and quality. Unsal and Taylor (2010) investigated sub-contracting problems associated with information asymmetry while Ceric (2010) investigated the role of moral hazard and adverse selection on procurement systems. This research goes further by identifying the causes and effects relationship between moral hazard and adverse selection on Ghanaian PPP construction projects. The research findings will serve as a guide for construction stakeholders in the PPP sector on the causes and effects of adverse selection and moral hazard, and how to mitigate these.

\section{EXPLORING AGENCY THEORY IN PPP CONSTRUCTION PROJECTS:}

The Principal-Agent problem is the situation in a contract where one of the parties involved in the contarct is better informed than the other party (Jäger, 2008). In PPP construction projects, normally, the government and a private sector firm(s) have a principal and agent relationship (Turner and Müller, 2004). The principal-agent relationship establishes a delegation of tasks between the principal and the agent where the principal depends on the agent to undertake a task on their behalf (Müller and Turner, 2005). Hence, it is assumed that an agent will try to maximise their benefit even when that may involve a higher damage to the client (Schieg, 2008). According to the Principal-Agent theory, this problem is characterised by the issues concerning the relationship between the principal and the agent, which might include adverse selection and moral hazard (Ceric, 2010; Ceric, 2003).

According to the Project Management Institute (2000), the project owner is a person or the group of people responsible for providing financial resources for the delivery and completion of the project (Project Management Institute, 2000). Ideally, in a PPP setting, the public sector engages the private sector to undertake activities required to finish the project. According to the PrincipalAgent theory, the relationship between the two parties also involves self-interest of each party (Schieg, 2008). When one of the two parties is better informed than the other, it is characterised by information asymmetry. Information asymmetries exist whenever the agent and principal do not possess the same level of information at the same time. The stakeholders in a PPP construction project are expected to work together to meet the goals of time, quality and cost. However, due to self-interest, they may not share all the information accrued. This normally leads to two different types of information asymmetries, namely: hidden characteristics and hidden information (Winch, 2010).

\section{Moral Hazard}

Moral hazard should not pose a challenge or problem when both the principal and agent share the same objective when conducting all the project required functions. Any misunderstanding related 
to which action(s) should be taken and at what time normally create the basis for agency costs (Loben, 2009). A moral hazard problem can be one of two potential cases, namely:

Case One:- The parties possess similar information at the time during which the relationship is established. Informational asymmetry arises immediately after signing the contract as the principal cannot verify and observe the efforts and actions of the agent, or in some cases, the principal cannot flawlessly control such efforts and actions. In modelling this condition, the assumption is made that the agent's effort post contract signature, is not confirmable and accordingly, this variable cannot be plainly added to the contract stipulations/ clauses.

Case Two:- Some moral hazard problems are attributed to informational asymmetries that occur before accomplishing the contract efforts - particularly, when the agent monitors the product of the environment's decision but the principal does not. Once the contract is signed, the uncertainty is identical for both the principal and agent, but before starting the contract action(s), the agent will have an informational benefit by observing an appropriate variable (Loben, 2009). Within this regard, this second type of moral hazard challenge is much less represented in extant literature. According to Chiocha (2009), in Malawi, a number of building project inspectors indulged in collusion as a result of moral hazard thereby bringing the concept of monitoring into disrepute.

\section{Adverse Selection}

An adverse selection problem occurs when the agent holds private information before the relationship begins. The principal can authenticate the agent's behavior - however, the cost of obtaining the optimal decision relies upon the agent's type which is private information considering the agent. Although the principal might be aware that the agent can be one of several possible types, the principal cannot identify such types without having access to the agent full details (Loben, 2009). In disparity to the moral hazard problem where the uncertainty is exogenous, in this instance, the uncertainty is exogenous to the principal. The adverse selection challenge exists not only when the agent's informal actions relate to their own private features, but also when there is asymmetric information relating to any variable relevant to the contracted partnership. A typical example is of a public agency which contracts a private firm for the building of a hospital while lacking knowledge concerning the most current technological innovations, regarding the building of hospitals (Loben, 2009). A study by Ameyaw et al. (2011) in Ghana showed that due to adverse selection, there has been corruption in project procurement right from project inception to completion

\section{CAUSES AND EFFECTS OF MORAL HAZARD AND ADVERSE SELECTION OF PPP PROJECTS:}

One of the main causes of information asymmetry problem is that effort dimensions are not verifiable as a significant cause. The extent of effort exerted in work cannot be specified in the 
contracts hence leading to problems - the agent then has the incentive to minimise effort when undertaking work to maximise profit (Guasch, 2004). Low transfer of risks causes moral hazard and adverse selection. (Boukendour, 2007). Inexperience as a cause occurs when inexperienced contractors bid for PPP projects and withhold vital information from the principal before the relationship begins (Allen, 2003).

Another major cause of moral hazard and adverse selection of PPP construction projects is low incentives. When the risks and liability of cost overruns are not tolerated by the party constructing, low incentive mentality to control costs prevails (Blanc-Brude, 2013). In renegotiation of contracts, renegotiation incidents being persistent in PPPs lead to agency problems (Guasch et al., 2008). There have been calls for laws that prevent renegotiation of contracts in PPPs by some procurement models, but many of these models cannot be adapted by modern contracts (Laffont 2003).

Lack of accurate information about project conditions is another cause of moral hazard and adverse selection. Due to the long-term scope of PPP projects, accurate information on the existing, future and indirect costs of the works are obscured. This increases the prevalence of moral hazard and adverse selection (Blanc-Brude, 2013; and Loben, 2009). Limited ability to commit to contractual obligations is also a cause and is referred to as conditions of restricted commitment (Iossa and Martimort, 2008). In these instances, contractual parties are unable to abide by their obligations spelt out in the contract (Estache and Wren-Lewis, 2008). Choosing the wrong party to execute the work leads to moral hazard and adverse selection problems. Adverse selection results when the contractor selects the wrong party (agent), to begin with. This leads to moral hazard problems of cost overruns and poor risk management (Loben, 2009).

Siphoning of funds is a significant effect arising from moral hazard and adverse selection. The agent of the contract may syphon funds, and this works against the principal hence, instead of focusing on work that drives success, the agent can divert monies for private consumption and remaining funds to create the impression of productivity (Chong et al., 2007). Information asymmetry stimulates opportunistic behaviour which is an effect of moral hazard and adverse selection (Schieg, 2008). In the project's bidding phase, the tenderer does not know clearly the bidder's technical strength and the bidder is also unclear of the tender's financial ability (Martimort and Straub, 2008). Consequences on profitability is another effect. Private investment becomes difficult to attract especially when projects are large and private sponsors are averse to risk (Iossa and Martimort, 2008). Moral hazard leads to negative implications for the enforceability of the contract (Chong et al., 2007).

Reduction of competition occurs because of moral hazard and adverse selection. When bidders develop an innovative offer, they risk losing the tender and not being repaid for the innovation (Badenfelt, 2008). This limits the number of bidders and successively failed bids erode competition as the opportunity to win a contract is outweighed by the cost of lost bids (Boukendour, 2007). 
Corruption is also an effect of moral hazard and adverse selection. The construction industry worldwide has a negative reputation for bribery and corruption incidents (Sohail and Cavill, 2008). Martimort and Straub (2008) suggest that countries with multi-level systems of government are more exposed to corruption. Consequently, dishonesty is a widespread effect of adverse selection and moral hazard and asymmetric information can engender dishonesty to create a major project risk in construction (Martimort and Straub, 2008). In addition, high transaction costs are a consequence of moral hazard and adverse selection. Transaction costs arise because the government negotiates with and monitors the private sector partners who have their interests and agendas (Muhwezi et al., 2014). Figure I below illustrates the conceptual framework for the study.

<Insert Figure I about Here>

\section{METHODOLOGY}

A questionnaire survey was used as the main instrument to collect research required data. Both primary and secondary quantitative data were utilized, and structural equation modeling (SEM) was the primary analytical tool for developing the research framework (Tong, 2007). Sample size has an important effect on model fit in SEM analysis and model testing. Tong (ibid) stressed that small sample size leads to more bias in model fit and makes the model ineffective. According to El-Gohary and El-Gohary (2016); El-Gohary (2014); El-Gohary (2012), a sample size of 100 is considered small leading to undesirable results in SEM; a fact also noted by El-Gohary (2009) and Iacobucci (2010). For optimal SEM analysis, a sample size of 200 or more with a specific number of variables is ideal for a good fit model analysis (Curran et al., 2004). The questionnaire comprised questions primarily closed-ended and scaled-response type. Respondents were asked to rank on a scale of 1-5 the relationship between effects and causes of moral hazard and adverse selection. The causes and effects of moral hazard and adverse selection were coded in the questionnaire and this was used in SEM analysis (refer to Tables I and II)

A purposive sampling technique was adopted which consisted identifying professionals involved in Public-Private-Partnership (PPP) construction projects. Purposive sampling is very useful for instances where the researcher needs to contact a targeted sample fast (Tongco, 2007). Furthermore, snowball-sampling technique was also used to secure an adequate sample size given the different challenges encountered in evaluating the population size (Creswell, 2005). This mixed-sampling process continued until a representative sample size of fifty-six (56) government agencies, consultancy firms and construction companies in charge of Public Private Partnership projects was obtained in Ghana. Questionnaires were distributed in the cities of Accra and Kumasi to five (5) respondents in each one of these companies and/ or agencies resulting in a total of two hundred and eighty (280) potential respondents. Two hundred and ten (210) useable questionnaires representing seventy-five percent $(75 \%)$ response rate were attained back. 
The SEM tool was adopted as the best tool for developing the structural model. According to Kline (2010), confirmatory factor analysis (CFA) and exploratory factor analysis (EFA) exist as the most useful approaches in analysing SEM variables (Bentler, 2005). The purpose of EFA is to explore the probable fundamental factor structure in a set of observed variables (Byrne, 2006). CFA conversely confirms already recognised factor structure of a set of observed variables (Hair et al., 2013). For this study, CFA was the best in analysing the constructs in the model and the causal relationship between the dependent and the independent variables. CFA was undertaken on the exogenous variables to define its best fit for the model. The main approaches used in SEM to suitably develop models are score reliability and validity, covariance analysis, z-tests, the test of significance and measure of goodness of fit of the model. Data retrieved from fieldwork was carefully reviewed then inputted into SPSS, and later extrapolated into STATA and AMOS for further analysis. P-values were used to explain the statistical significance. This was done by convention and further compared to past studies such as Kwofie et al. (2014). The p-value was set at 0.05 and infers a ninety-five percent chance that the population mean is within a stated range of values. As recommended by Hair et al. (2014) and Eid and El-Gohary (2013), this research adopted multi approaches to assess model fit. Practically, the standardised root mean square residual (SRMR), goodness of fit index (GFI), bentler comparative fit index (CFI), chi-square $\left(\chi^{2}\right)$, satorrabentler scaled chi-square ( $\mathrm{S}-\mathrm{B} \chi 2)$, root mean square error of approximation (with its $90 \%$ or $95 \%$ confidence interval) and root mean square error of approximation (RMSEA) which deliver the essential signs of how best the theory fits the data (Hair et al., 2014). A mixture of incremental/comparative fit indices and absolute fit index is however recommended for SEM analysis.

Fit indexes of CFI, $\chi 2$, GFI and $\mathrm{S}-\mathrm{B} \chi 2$ are under the incremental/ comparative fit indices and RMSEA and SRMR instead, are under the absolute fit indices (Kline, 2010). The RMSEA and SRMR further define how best a model fits the data and indicates if proposed model is the best fit or not (McDonald and Ho, 2002). This research utilised three indices, namely: CFI, RMSEA and GFI. This was done to achieve a robust standard to assess the model fit. The $\chi 2$ was chosen to evaluate the acceptance of the mode generated. By convention, GFI result nearer to 0.95 or greater than 0.90 is appropriate for model test of fit (Kline, 2010). According to Wong (2011), the satisfactory or acceptable cut-off benchmarks of fit statistics are: $\mathrm{CFI}=$ value should be $\geq 0.95$ for good fit and 0.90 for acceptable fit; chi-square $\left(\chi^{2}\right)$ ratio to $\mathrm{df} \leq 3$ or 5 with an insignificant or significant $p$ value ( $\mathrm{p}>0.05$ ); $\mathrm{SRMR}=$ value should be $\leq 0.05$ as good fit and $\leq 0.08$ for acceptable fit (value of 0.1 is also acceptable); RMSEA = value should be $<0.05$ for good fit (values $<$ and 0.08 indicate a reasonable and acceptable error of approximation and values of $>0.10$ suggests a poor fit), and finally, RMSEA at $90 \% \mathrm{CI}=$ values to be $<0.05$ to 0.08 with confidence interval.

\section{DATA ANALYSIS AND DISCUSSION:}

Under the SEM technique, models which will be estimated are normally represented in graphical diagrams. These diagrams indicate the assumed relationship(s) between the variables by linking 
arrows among the independent and dependent variables. It is recommended that a very stable identified model must indicate a positive degree of freedom for the parameters in the overidentified model (Lei and $\mathrm{Wu}, 2008$ ). In this study, a preliminary analysis by way of CFA produced values of 2 and 14 as minimum and maximum degrees of freedom respectively. This proves a very suitable positive value of the degree of freedom. It is inferred that this model can be estimated.

\section{Confirmatory Factor Analysis (CFA) of Unobserved Constructs:}

CFA is a statistical method that verifies factor structure of a set of observed variables. It is normally used in the measurement of SEM models. The assessment of independent and dependent variables as being enough indicators is crucial in evaluating measurement invariance (MI). CFA should firstly be done on every latent variable by evaluating the coefficients and confirming the factor structure of every variable. This is to prevent any possible MI which may affect the good-fit of the model. If the fit of each model is good and the item loading is adequate, it is assumed that the indicators of the factors are fitting. The causes and effects of moral hazard and adverse selection were coded for SEM analysis (refer to Tables I and II).

$<$ Insert Tables I and II about Here>

\section{Analysis of Low incentives to control costs:}

Low incentives to control costs was analysed using the responses obtained from the data collection process and CFA on nine (9) variables in the construct. There is a need to analytically evaluate all the variables to settle on the ones in the model, which succinctly measure and explain a construct (Bentler, 2005; Wong, 2010). Usually, correlations, standard errors and standardised residual covariance are important guidelines in choosing the most acceptable variables which must be in the construct for further analysis (Field, 2009). From Table IIIa and b, the variables C1A, C1E, $\mathrm{C} 1 \mathrm{~F}$ and $\mathrm{C} 1 \mathrm{G}$ were excluded. The remaining five variables were subjected to detailed CFA tests. An accurate and robust SEM should have both fixed and free parameters to be estimated from the data (Bentler, 2005). Their significance, validity, model fit and parameter estimates were found.

<Insert Tables III (a) and III (b) about Here>

The model fit assessment must utilise multiple standards of both absolute and incremental fit indices to support the chi-square test. Although chi-square is a good measure of fit, it is affected by the sample size and hence, gives erroneous probability figures (Byrne, 2006). Consequently, the satorra-bentler scaled chi-square $\left(\mathrm{S}-\mathrm{B} \chi_{2}\right.$ ) was used as it provides a much better fit (Iacobucci, 2010). From Table III (a) and (b), the CFI and GFI values were 0.951 and 0.983 correspondingly. Bentler (2005) suggests that CFI values above 0.90 provide a good fit whereas, GFI test values of 0.90 and above also provide a good fit (Lei and $\mathrm{Wu}, 2008$ ). The RMSEA value was 0.065 and illustrates that a good fit was obtained (c.f. Bentler, 2005; Lei and Wu, 2008). Sample data on low incentives to control cost measurement model produced $S-B \chi^{2}$ to be 9.481 with a degree of 
freedom (df) equal 5 while the sig. value (p-value) was 0.091 . The overall goodness of fit is revealed by the magnitude of discrepancy amongst the sample covariance matrix and the covariance matrix (population) inferred by the model such that the good model fit must possess $\mathrm{df}$ value $>0$ and sig. values ( $\mathrm{p}$ values) $>0.05$.

A p-value $>0.05$ related to $S-B \chi^{2}$ shows that the difference between the sample data and low incentives to control cost measurement model is insignificant and hence, the model fits the data (Kline, 2010). According to Hair et al., (2014) and Kaplan (2009), Z-values (critical ratios) and coefficient of determination $\left(\mathrm{R}^{2}\right)$ figures are important in explaining the significance and effects of the different parameters within a model. Correlation values and standard errors showed that all the coefficient values were less than 1.00. Z statistics had a positive value higher than 1.96 and therefore deemed to be very suitable. The $Z$ test statistics showed the significance or otherwise of the path coefficients of the model. As indicated by Kline (2010), utilising a two-tailed Z-test with a significance level of 0.05 , path coefficient is significant if $\mathrm{Z}$ statistics exceeds 1.96 . All Z-values resulted from the data analysis exceeded 1.96 and therefore implies that the indicator variables loadings are very significant. $\mathrm{R}^{2}$, which is the coefficient of determination, measures the predictive accuracy of the model. The effect of measurement of $R^{2}$ spans between 0 and 1 . The value 1 signifies perfect accuracy of prediction (Hair et al., 2014). A value of 0.75 or greater is seen as substantial, 0.50 is moderate while 0.25 or lesser signifies reflects weak accuracy of prediction (Henseler et al., 2010). From the results of CFA analysis, the robust fit indices met the prescribed cut-off criteria and hence the model sufficiently fits the data. All parameters estimates were found to be both statistically significant and viable.

\section{Analysis of the Wrong Party Chosen to Execute Project}

A preliminary CFA analysis was conducted to identify the variables to be added in the CFA analysis to evaluate model fitting and the variables $\mathrm{C} 2 \mathrm{~F}$ and $\mathrm{C} 2 \mathrm{G}$ were excluded. The remaining seven variables were subject to detailed CFA tests. This analysis detected the importance of the indicator variables to the factor, the significance of variables, factor structure, parameter estimation and model fit.

\section{$<$ Insert Tables IV (a) and IV (b) about Here>}

From Tables IV (a) and (b), S - B $\chi_{2}$ value was 28.269 with 14 degrees of freedom (df), a p-value of 0.013 , the CFI value was 0.787 and the GFI value was 0.963 . This is found to be close to the standard cut-off value of $x \geq 0.90$ (acceptable) and $x \geq 0.95$ (good fit). It can, therefore, be observed to be a good fit. Furthermore, the RMSEA value was 0.07, which is acceptable since the cut-off values are $x \leq 0.080$ (acceptable) and $x \leq 0.05$ (good fit) (Kline, 2010). In addition, the Z-statistic figures were above 1.96 and the resultant significant test figures below $0.05(p<0.05)$. These statistics proves that the research results are both statistically significant and acceptable. In conclusion, the robust fit indices met the prescribed cut-off points, and the model fits the data. 


\section{Analysis of Low Transfer of Risk}

This construct was explained by nine indicator variables (effects). The variables $\mathrm{C} 3 \mathrm{~F}, \mathrm{C} 3 \mathrm{H}$ and C3I were excluded after conducting the CFA. The remaining six variables were subject to detailed CFA tests (refer to Tables V (a) and (b).

<Insert Tables V (a) and V (b) About Here>

Low transfer of risk factor model had an $S-B \chi^{2}$ figure of 16.395 with 9 degrees of freedom and a corresponding $p$-value was 0.059 . Chi-square figure above $0.05(\mathrm{p}>0.05)$ which implies that the difference between the hypothesised low transfer of risk factor model and the sample data is not significant and indicates that the data fits the model well. It reveals that there is no inconsistency among the sample and population (Kline, 2010). The robust CFI and GFI indices were 0.951 and 0.974 correspondingly. The RMSEA value was 0.063 , which is deemed acceptable. As such, it is concluded that this model sufficiently fits the data and therefore has a good fit. From Tables Va and $b$, the standard errors were all below 1.00 and were therefore acceptable. The $\mathrm{Z}$ values were all above the standard value of 1.96 based on the probability level of 0.05 . All the p-values were below 0.05 . This proves that the variables were genuinely statistically significant to the factor. The $\mathrm{R}^{2}$ values had moderate and weak levels of predictive accuracy. In summary, the robust fit indices satisfied the cut-off benchmarks. Therefore, low transfer of risk factor model has acceptable fit to the sample data.

Analysis of Lack of Accurate Information about Project Condition:

After preliminary CFA tests, variables C4A, C4B, C4D and C4F were excluded. Hence, they did not form part of the detailed CFA analysis. The sample data on this model gave an $S-B \chi 2$ value of 8.94 with 5 degrees of freedom and the p-value for the sample size of 210 is 0.111 . Since chisquare value is greater than 0.05 , it implies that the difference between the sample data and the hypothesised lack of accurate information about project condition factor is not significant. The fit function is good and well-specified leading to the model being retained (refer to Tables VI (a) and (b).

<Insert Tables VI (a) and VI (b) about Here>

The robust CFI and GFI indices were 0.885 and 0.984 respectively. The GFI is very near to the upper limit of 1.00 and therefore illustrates a good fit. According to Iacobucci (2010), a model is a good fit if its CFI or GFI is more than the cut-off figure of 0.95. The RMSEA value is 0.061, which is acceptable. From Tables Via and b, all the standard errors were below 1.00 and therefore adequate and reasonable. The $\mathrm{Z}$ values were all above the standard value of 1.96 based on the probability level of 0.05 . Four of the p-values were below 0.05 . This proves that many of the 
variables were genuinely statistically significant to the factor. The parameter estimates indicated satisfactory linkages with the factor construct. The $\mathrm{R}^{2}$ values had moderate and weak levels of predictive accuracy. This indicates a good fitting model for lack of accurate information about project condition factor.

Analysis of Effort Dimensions which are not Verifiable:

The effort dimensions, which are not verifiable factor, was defined by nine variables. After preliminary CFA tests were conducted, three variables were excluded, namely C5B, C4F and C4H. The remaining six variables were subject to detailed CFA tests and analysis (refer to Tables VII (a) and VII (b).

<Insert Tables VII (a) and VII(b) about Here>

In assessing the goodness of fit, the sample data for effort dimensions, which are not verifiable factor, generated an $\mathrm{S}-\mathrm{B} \chi^{2}$ value of 19.407 with 9 degrees of freedom and complementary probability of 0.022 . Additionally, the robust CFI and GFI were 0.803 and 0.97 respectively. The robust RMSEA figure of 0.074 is acceptable conventionally and therefore a clear indication of good fit of model to sample. In an ideal situation, a model that fits should have parameter estimates of significance especially the $\mathrm{Z}$ test to help in knowing if the structure factor is feasible. From Tables VIIa and $b$, the values were above the standard of 1.96. The associated p-values were all below 0.05 except for one variable. The $\mathrm{R}^{2}$ values had moderate and weak levels of predictive accuracy. In summary, the robust fit indices were good fit and the parameter estimates were feasible and significant statistically.

\section{Analysis of Regeneration of Contracts}

The regeneration of contracts factor was defined by nine variables. After preliminary CFA tests were conducted, five variables were excluded, namely $\mathrm{C} 6 \mathrm{~B}, \mathrm{C} 6 \mathrm{C}, \mathrm{C} 6 \mathrm{D}, \mathrm{C6E}$ and $\mathrm{C} 6 \mathrm{~F}$. The remaining four variables were subject to detailed CFA tests and analysis. To know how best the model fits the factor and variables, tests were conducted for the statistical significance at probability level of 0.05 , fit statistics and standardised residual covariance distribution matrix (refer to Tables VIII (a) and (b).

<Insert Tables VIII (a) and VIII (b) about Here>

In assessing the goodness of fit, the sample data for regeneration of contracts factor generated an $\mathrm{S}-\mathrm{B} \chi_{2}$ value of 1.917 with 2 degrees of freedom and probability of 0.384 . Furthermore, the robust CFI and GFI were 1.000 and 0.995 correspondingly. The robust RMSEA figure of 0.074 is acceptable standardly and therefore provide an unconditional indication of good fit of the model to the research sample. In an ideal situation, a model that fits should have parameter estimates of 
significance especially the $\mathrm{Z}$ test to help in knowing if the structure factor is feasible. The values were above the conventional value of 1.96 . The associated $p$-values were all 0.00 , which is below 0.05 . The $\mathrm{R}^{2}$ values had strong and weak levels of predictive accuracy. The robust fit indices are therefore showing a good fit, and the parameter estimates are feasible and statistically significant.

Analysis of Limited Ability to Commit to Contractual Obligations:

The limited ability to commit to contractual obligations factor was defined by nine variables. After preliminary CFA tests were conducted, five variables were excluded, namely C7A, C7C, C7D, $\mathrm{C} 7 \mathrm{H}$ and C7I. Their significance, validity, model fit and parameter estimates were found to be good (refer to Tables IX (a) and (b).

<Insert Tables IX (a) and IX (b) about Here>

The robust CFI and GFI indices were 0.935 and 0.989 respectively. The CFI and GFI are very near to the upper limit of 1.00 and therefore show an indication of a good fit. According to Iacobucci (2010), a model is a good fit if its CFI or GFI is more than the cut-off figure of 0.95. The RMSEA value is 0.082 , which is acceptable. All the standard errors were below 1.00 and hence adequate and reasonable. The $\mathrm{Z}$ values except one were all above the standard value of 1.96 based on the probability level of 0.05 . Four of the p-values were below 0.05 . This proves that many of the variables were genuinely statistically significant to the factor. The parameter estimates indicated satisfactory linkages with the factor construct. The $\mathrm{R}^{2}$ values had a mixture of strong and weak levels of predictive accuracy. This indicates a good fitting model for limited ability to commit to contractual obligations factor.

Analysis of Inexperience:

Analysis of Inexperience construct was explained by nine indicator variables (effects). After conducting the preliminary CFA analysis, two (2) variables were excluded, namely $\mathrm{C} 8 \mathrm{E}$ and $\mathrm{C} 8 \mathrm{H}$. Inexperience factor was analysed with all the 210 responses obtained from the research survey. Tests were conducted for the statistical significance at probability level of five percent, fit statistics and standardised residual covariance distribution matrix (refer to Tables X (a) and (b).

<Insert Tables X (a) and X (b) about Here>

$\mathrm{S}-\mathrm{B} \chi_{2}$ value was 18.714 with 14 degrees of freedom (df) and a $\mathrm{p}$-value of 0.176 . The CFI value was 0.955 and GFI value was 0.977 . This is close to the standard cut-off value of $x \geq 0.90$ (acceptable) and $\mathrm{x} \geq 0.95$ (good fit). As such, it is observed to be good fit. Furthermore, the RMSEA value was 0.00 , which is good fit since the cut-off values are $x \leq 0.080$ (acceptable) and $x \leq 0.05$ (good fit) (Kline, 2010). The Z-statistic figures except one were above 1.96 and the resultant 
significant test figures below $0.05(\mathrm{p}<0.05)$. This proves results are statistically significant and acceptable. Accordingly, it can be construed from results of the CFA analysis that, robust fit indices met the prescribed cut-off points and the model fits the data. The parameter estimates were also statistically significant.

\section{Summary of Measurement Model}

Table XI and Figure II below summarise the relationships between causes and effects of moral hazard and adverse selection of PPP construction projects.

\section{$<$ Insert Table XI about Here> \\ $<$ Insert Figure II about Here>}

\section{Discussion}

Siphoning of funds arises due to moral hazard and adverse selection. The agent could siphon funds and this works against the principal hence, instead of focusing on work that drives success, the agent can divert monies for private consumption and remaining funds to create the impression of productivity. Monitoring this situation brings about three challenges (Chong et al., 2007). First, firms may attempt to win the contract with limited effort and with the premeditated intention of siphoning all funds. Second, a firm which has worked efficiently according to contract may start siphoning funds whilst waiting to exercise the option of revealing success at a future more convenient date. Third, towards the end of contract, a firm may cease exerting effort and start siphoning funds, because the probability of success fails to justify the exertion of more effort. For instance, a construction company may succeed at the end of a large project and then delay completion of the less demanding activities over time to stretch out payments received from the principal (Chong et al., 2007). Consequences on profitability is another effect. Because of the inherent challenges involved in producing accurate estimates, the firm's profits are largely uncertain before the operation phase starts (Chong et al., 2007). Private investment becomes difficult to attract especially when projects are large and private sponsors are averse to risk (Iossa and Martimort, 2008). In Europe, cross border infrastructure has received little concern from private financiers. Even when private investors turn up, they tend to behave opportunistically leading to moral hazard (Chong et al., 2007).

\section{CONCLUSION}

The research identified the causes and effects of moral hazard and adverse selection on PPP construction projects. Research findings have contributed to past studies and existing knowledge on PPP and information asymmetry, and have shed much needed light onto moral hazard and adverse selection. SEM was used to explore the causal relationships between the causes and effects of moral hazard and adverse selection problems in PPP construction projects. Causes being the independent variables (IV) and effects the dependent variables (DV). The measured model was used to predict, estimate and depict the complex causal relationships (i.e. the directionality). It 
further showed the degree of association and isolation of the unobserved variables on the indicator factors. CFA was used to evaluate the fit of items to latent constructs. Since the fit of each model was good and the item loadings were adequate, it was assumed that the indicators of the factors were fitting. The diagnostic fit analysis was conducted using robust maximum likelihood to test statistical significance of parameter estimates and the results indicated a good fit. The majority of previous studies had assessed the causal relationships between different variables using univariate statistical tools like MANOVA, ANOVA or multiple regression modelling to produce models. Yet these models are unable to adequately illustrate the complete relationships among the dependent variables and independent variables because they condense and relate several independent variables into one dependent variable. In this research, SEM was utilized because it provides a better approach in investigating the causal relationships in a model and the direction of influence within it. Moreover, it can be concluded that this study is one of the first studies using SEM to investigate causal and effects relationships of moral hazard and adverse selection on PPP construction projects. However, the model developed was not validated and so consequently, future studies are required to: validate the model developed; and expand the relevance of the model to other national and industry settings. Execution of PPP projects in African countries still remains a significant challenge and is mainly due to information asymmetry. The research findings will serve as a guide for construction stakeholders in the PPP sector on the causes and effects of adverse selection and moral hazard, and how to mitigate these. Moral hazard and adverse selection are serious problems bedeviling the construction industries of developing countries including Ghana. Hence, it is essential to introduce the use of incentives and monitoring mechanism into project contracts. This will go a long way to reduce information asymmetry. 


\section{REFERENCES}

Ahadzi, M. And Bowles, G. (2001) The Private Finance Initiative: The Procurement Process in Perspective, in Akintoye, A. Ed., 17th Annual ARCOM Conference, 5-7 September, University of Salford, Association of Researchers in Construction Management, Vol. 1, No. 1, pp. 991-999.

Allen G., (2003) The Private Finance Initiative, House of Commons Research Paper 03/79, Economic Policy and Statistics Section. Available via: http://researchbriefings.parliament.uk/ResearchBriefing/Summary/RP03-79\#fullreport [Accessed: December, 2017].

Ameyaw, C., Mensah, S. and Osei-Tutu E. (2011). "Challenges facing the smooth implementation of Act 663, 2003 of Ghana”, West African Built Environment Research (WABER) Conference, University of Reading, 2011

Bentler, P. M. (2005) EQS 6 Structural Equation Program Manual, Encino. CA: Multivariate Software

Biong, H. (2013) Choice of Subcontractor in Markets with Asymmetric Information: Reputation and Price Effects. Journal of Business and Industrial Marketing Vol. 28, No. 2, pp. 60-71.

Blanc-Brude, F. (2008) Public-Private Risk Transfer - Public-Private Partnerships, Long-Term Contracts and Price Discovery, King's College London.

Blanc-Brude, F. (2013) Towards Efficient Benchmarks for Infrastructure Equity Investment, EDHEC-Risk Institute. Available via: http://docs.edhecrisk.com/mrk/000000/Press/Towards_Efficient_Benchmarks.pdf [Accessed: December, 2017].

Blombäck, A. And Axelsson, B. (2007) The Role of Corporate Brand Image in the Selection of New Subcontractors, Journal of Business and Industrial Marketing, Vol. 22, No. 6, pp. 418430.

Bollen K. A., Kirby, J. B., Curran, P. J., Paxton, P. M. and Chen, F. (2007) Latent Variable Models Under Misspecification: Two-Stage Least Squares (TSLS) and Maximum Likelihood (ML) Estimators. Sociological Methods and Research, Vol. 36, No. 8, pp. 48-86.

Bordat, C., Mccullouch, B., Sinha, K., Labi, S. (2004) An Analysis of Cost Overruns and Time Delays of INDOT Projects. Joint Transportation Research Program, Paper 11. Available via: http://docs.lib.purdue.edu/cgi/viewcontent.cgi?article=1482\&context=jtrp [Accessed: December, 2017].

Boukendour, S. (2007) Preventing Post-Contractual Opportunism by an Option to Switch from one Contract to Another, Construction Management And Economics, Vol. 25, No. 7, pp. 723-727.

Buvik, A. and Rokkan, A. (2003) Inter-Firm Cooperation and the Problem of Free Riding Behaviour: An Empirical Study of Voluntary Retail Chains, Journal of Purchasing and Supply Management, Vol. 9, No. 5-6, pp. 247-256.

Ceric, A. (2003) A Framework for Process-Driven Risk Management in Construction Projects, $\mathrm{PhD}$ Thesis, Research Institute for the Built and Human Environment, School of 
Construction and Property Management, University Of Salford, Salford. Available via: http://usir.salford.ac.uk/2184/ [Accessed: December, 2017].

Ceric, A. (2010) The Impact of Asymmetric Information on Communication in Construction Projects, Working Paper Proceedings, Engineering Projects Organizations Conference, South Lake Tahoe, California, November 4-7.

Ceric, A. (2011) Minimizing Communication Risk in Construction Projects: A Delphi Study of the Key Role of Projects Managers, Working Paper Proceedings, Engineering Projects Organizations Conference, Estes Park, Colorado, August 9-11

Chan, A.P.C. and Tam, C.M. (2000) Factors Affecting the Quality of Building Projects in Hong Kong. International Journal of Quality and Reliability Management, Vol 17, No. 4, pp. 423-442.

Chiocha, C. I. M. (2009), Corruption and its effects on the development of the Construction Industry in Malawi. PhD Dissertation presented to the Faculty of Engineering, the Built Environment and Information Technology at the Nelson Mandela Metropolitan University

Chong E., Huet, F., Saussier, S. and Steiner, F. (2007) Public-Private Partnerships and Prices: Evidence from Water Distribution in France, Review of Industrial Organisation, Vol. 29, No. 3, pp. 149-169.

Corvellec, H. and Macheridis, N. (2010) The Moral Responsibilities of Project Selectors, International Journal of Project Management, Vol. 28, No. 3, pp. 212-219.

Creedy, G. (2006) Risk Factors Leading Cost Overrun in the Delivery of Highway Construction Projects. Doctoral Thesis, Queensland University of Technology. Available via: https://eprints.qut.edu.au/16399/1/Garry_Creedy_Thesis.pdf [Accessed: December, 2017].

Cresswell, J.W. (2005) Research Design: Qualitative, Quantitative and Mixed Methods Approaches, London: Sage Publications.

Curran, P.J., Bauer, D.J. and Willoughby, M.T. (2004) Testing Main Effects and Interactions in Latent Curve Analysis. Psychological Methods, Vol. 9, No. 2, pp. 220-237.

De-Palma, A., Leruth, L., Pruneir, G. (2009) Towards a Principal-Agent Based Typology of Risks In Public-Private Partnerships, IMF. Available via: https://www.imf.org/en/Publications/WP/Issues/2016/12/31/Towards-a-Principal-AgentBased-Typology-of-Risks-in-Public-Private-Partnerships-23190 [Accessed: December, 2017].

Eid, R., And El-Gohary, H, (2013) The Impact of E-Marketing Use on Small Business Enterprises Marketing Success: The Case Of UK Companies, The Service Industries Journal, Vol. 33, No. 1, pp: 31-50.

El-Gohary, H. and El-Gohary, Z. (2016) An Attempt to Explore Electronic Marketing Adoption And Implementation Aspects in Developing Countries: The Case of Egypt, International Journal of Customer Relationship Marketing And Management (IJCRMM), Vol. 7, No. 4, pp: $1-26$. 
El-Gohary, H, (2012) Factors Affecting E-Marketing Adoption and Implementation in Tourism Firms: An Empirical Investigation of Egyptian Small Tourism Organizations, Tourism Management, Vol. 33, No. 5, pp: 1256-1269.

El-Gohary, H, (2011) Electronic Marketing Practises in Developing Countries: The Case of Egyptian Business Enterprises, Germany, VDM Verlag Dr Müller, ISBN: 978-3-63927461-5.

El-Gohary, H. (2009) The Impact of E-Marketing Practices on Market Performance of Small Business Enterprises: An Empirical Investigation, PhD, University of Bradford, Bradford, UK. Available via: https://bradscholars.brad.ac.uk/handle/10454/4308 [Accessed: December, 2017].

Estache, A. And Wren-Lewis, L. (2008) Toward a Theory of Regulation for Developing Countries: Following Jean-Jacques Laffont's Lead, Journal of Economic Literature, Vol. 47, No. 3, pp. 729-770

Field, A.P. (2005) Discovering Statistics Using SPSS ( $2^{\text {nd }}$ Ed.). London: Sage Publications.

Field, A. (2009) Discovering Statistics Using SPSS for Windows, 3rd Edition, London: Sage Publications.

Flyvbjerg, B. And Holm, M. S. (2003) How Common and How Large are Cost Overruns in Transport Infrastructure Projects? Transport Reviews. Vol. 23, No. 1, pp. 71-88.

Flyvbjerg, B., Holm, M. S. and Buhl, S. (2004) What Causes Cost Overrun in Transport Infrastructure Projects? Transport Reviews. Vol. 24, No. 1, pp. 3-18.

Gao, S. (2008) Research on the Role of Attribution in Reading Comprehension Among Chinese EFL Learners. Sino-US English Teaching, Vol. 5, No. 10, pp. 30-34.

Gray, C.F. And Larsson, E.W. (2008) Project Management: The Managerial Process. Boston: Irwin Mcgraw Hill.

Guasch, J. L., Laffont, J.J. and Straub, S. (2008) Renegotiation of Concession Contracts in Latin America, Evidence from the Water and Transport Sectors, International Journal of Industrial Organization, Vol. 26, No. 2, pp. 421-442.

Hair, J.F., Black, W.C., Babin, B.J., Anderson, R.E. and Tatham, R.L. (2010) Multivariate Data Analysis With Readings. 7 Ed. Upper Saddle River, N.J: Pearson/Prentice Hall

Hair, J. F., Hult, G. T. M., Ringle, C. M. and Sarstedt, M. (2013) A Primer on Partial Least Squares Structural Equation Modeling (PLS-SEM). Thousand Oaks: Sage Publications.

Hair, J. F., Sarstedt, M., Hopkins, L. and Kuppelwieser, V. J. (2014) Partial Least Squares Structural Equation Modeling (PLS-SEM): An Emerging Tool in Business Research, European Business Review, Vol. 26, No. 2, pp. 106-121.

Jäger, C. (2008) The Principal-Agent-Theory Within the Context of Economic Sciences, Norderstadt, Herstellung Und Verlag, Books on Demand Gmbh

Kaplan, D. (2009) Structural Equation Modeling: Foundations and Extensions (2nd Ed.). Thousand Oaks, CA: Sage Publications.

Kleinbaum, D.G., Kupper, L.L. and Muller K.E. (1988) Applied Regression Analysis and Other Multivariate Methods, Belmont, CA: Duxbury Press. 
Kline, R.B. (2010) Principles and Practice of Structural Equation Modeling. 3rd Edition. New York: Guilford Press.

Kwofie, T. E., Fugar, F. D.K, Adinyira, E. and Ahadzie, D. K. (2014) A Conceptual Framework for Evaluating Communication Performance Among Mass Housing Project Team. In Dr. Obuks Ejohwomu And Olalekan Oshodi (Eds) Procs. $3^{\text {rd }}$ International Conference on Infrastructure Development in Africa, 17-19 March, 2014, Abeokuta, Nigeria, pp. 6-21.

Kwofie, T. E. (2014) Contribution of Unique Features of Mass Housing Projects to Project Team Communication Performance. An Unpublished PhD Thesis Submitted to the Department of Building Technology, KNUST, Ghana. Available via: http://ir.knust.edu.gh/xmlui/handle/123456789/8347 [Accessed: December, 2017].

Iossa E. And Martimort D. (2008) The Simple Micro-Economics of Public Private Partnerships, CEIS Tor Vergata, Research Paper Series, Vol. 6, No. 12, pp. 139.

Ive, G., And Chang, C.Y. (2007) The Principle of Inconsistent Trinity in the Selection of Procurement Systems, Construction Management and Economics, Vol. 25, No. 7, pp. 677690.

Laffont, J.J. and Tirole, J. (1986) Using Cost Observations to Regulate Firms, Journal of Political Economy, Vol. 94, No. 1, pp. 614-641.

Laffont, J.J. And Tirole, J. (1993) A Theory of Incentives in Procurement and Regulation. Cambridge, Mass.: MIT Press.

Lattin, J., Carroll, J.D. and Green, P.E. (2003) Principal Components Analysis and Exploratory Factor Analysis in Analyzing Multivariate Data, C.A.: Pacific Grove.

Lei, M. and Lomax, R. G. (2005) The Effect of Varying Degrees of Nonnormality in Structural Equation Modeling. Structural Equation Modeling: A Multidisciplinary Journal, Vol. 12, No. 1, pp. 1-27.

Lei, P. and Wu, Q. (2008) Introduction to Structural Equation Modeling: Issues and Practical Considerations. Educational Measurement, An NCME Instructional Module, Vol. 26, No. 3, pp. 33-43.

Li, B., Akintoye, A., Edwards, P.J. and Hardcastle, C. (2005) Perceptions of Positive and Negative Factors Influencing the Attractiveness of PPP/PFI Procurement for Construction Projects in the UK: Findings from a Questionnaire Survey. Engineering Construction and Architectural Management, Vol. 12, No. 2, pp. 125-148.

Lo, S. M. (1999) A Fire Safety Assessment System for Existing Buildings. Fire Technologies, Vol. 35, No. 2, pp. 131-152.

Lobner, L. (2009) How Well do Public-Private Partnerships Work? Unpublished Masters Thesis Submitted To Wien University.

Martimort, D. and Straub, S. (2008) Infrastructure Privatization and Changes in Corruption Patterns: The Roots of Public Discontent, Journal of Development Economics, Vol. 90, No. 1, pp. 69-84.

Mcdonald, R. P. and Ho, M.H. R. (2002) Principles and Practice in Reporting Structural Equation Analyses. Psychological Methods, Vol. 7, pp. 64-82. 
Monteiro, R.S. (2010), Risk Management, In Hodge, G., Greve, C. and Boardman, A. Eds., International Handbook on Public-Private Partnerships (Willey-Blackwell, Oxford), Vol. 1, No. 1, pp. 262-291.

Mottmac Donald (2002) Review of Large Public Procurement in the UK. Croydon: Mott Macdonald. Available via: http://infrastructureaustralia.gov.au/policypublications/publications/Review-of-Large-Public-Procurement-The-Mott-McDonald-

Report-2002.aspx [Accessed: December, 2017].

Ministry of Finance and Economic Planning MOFEP (2011) National Policy on Public-Private Partnerships. Government of Ghana, Ghana. Available via: https://www.mofep.gov.gh/ecomomic\%20reports/national-policy-on-public-privatepartnership-PPP/2012-02-28 [Accessed: December, 2017].

Müller, R. and Turner, J.R. (2005) The Impact of Principal-Agent Relationship and Contract Type on Communication Between Project Owner and Manager, International Journal of Project Management, Vol. 23, No. 5, pp. 398-403.

Muthén, L. K. and Muthén, B. O. (2002) How to Use a Monte Carlo Study to Decide on Sample Size and Determine Power. Structural Equation Modeling, Vol. 4, pp. 599-620.

Muhwezi, M. (2009) Horizontal Collaborative Purchasing in the Ugandan Public Sector; An Exploratory Study. International Review of Business Research Papers, Vol. 5, No. 2, Pp. 223-243.

National Audit Office (NAO) (2009) Performance of PFI Construction. A Review by the Private Finance Practice. Available via: https://www.nao.org.uk/wpcontent/uploads/2009/10/2009_performance_pfi_construction.pdf [Accessed: December, 2017].

Norusis, M.J. (1993) SPSS for Windows Professional Statistic Release 6.0, Chicago, IL: SPSS.

Osei-Kyei R., Dansoh, A. and Ofori-Kuragu, J. K. (2014) Reasons for Adopting Public-Private Partnership (PPP) For Construction Projects in Ghana, International Journal of Construction Management Vol. 14, No. 4, pp. 227-238.

Ouattara, A.K. (2009) Effective Quality Incentives in Public Procurement: A Multi-Cases Analysis of Experience Goods/Services. Unpublished Master's Thesis, Molde University College.

Pana, R. M. (2010) Ownership Structure in Romanian Listed Companies a Corporate Governance and Corporate Performance Perspective. Unpublished Msc Thesis Aarhus University School of Business.

Project Management Institute (2000) A Guide to the Project Management Body of Knowledge, Newton Square, Pennsylvania. Available via: http://www.cs.bilkent.edu.tr/ cagatay/cs413/PMBOK.pdf [Accessed: December, 2017].

Sarantakos, S. (2005) Social Research, 3rd Ed, Melbourne, Victoria: Palgrave Macmillan.

Schieg, M. (2008) Strategies for Avoiding Asymmetric Information in Construction Project Management, Journal of Business Economics and Management, Vol. 9, No. 1, pp. 47-51.

Sohail, M. and Cavill, S. (2008) Water For The Poor: Corruption in Water Supply and Sanitation. In Transparency International (Ed.), Global Corruption Report 2008: Corruption in the 
Water Sector, Cambridge: Cambridge University Press, pp. 44-52. Available via: https://www.transparency.org/topic/detail/water [Accessed: December, 2017].

Tabachnick, B.G. and Fidell L.S. (2001) Using Multivariate Statistics, Allyn and Bacon: Boston.

Tadelis, S. (2002) Complexity, Flexibility, and the Make-or-Buy Decision, American Economic Review; Vol. 92, No. 2, pp. 433-437.

Tah, J.H.M. and Carr, V. (2000) A Proposal for Construction Project Risk Assessment using Fuzzy Logic, Construction Management and Economics, Vol 18, No. 4, pp. 491-500.

Tong, D.Y. (2007) An Empirical Study of E-Recruitment Technology Adoption in Malaysia: Assessment of Modified Technology Acceptance Model. Multimedia University, Malaysia.

Tongco, M. D. (2007) Purposive Sampling as a Tool for Informant Selection. A Journal of Plant, People and Applied Research Ethnobotany Research and Applications, Vol 1, No. 1, pp. $1-12$.

Turner, R. and Müller, R. (2004) Communication and Cooperation on Projects Between the Project Owner as Principal and the Project Manager as Agent, European Management Journal, Vol. 22, No. 3, pp. 327-336.

Unsal, H.I., And Taylor, J.E. (2010) Modelling Inter-Firm Dependency: A Game-Theoretic Simulation to Examine the Hold-Up Problem in Project Networks, Journal of Construction Engineering and Management, Vol. 137, No. 4. Available via: https://ascelibrary.org/doi/10.1061/\%28ASCE\%29CO.1943-7862.0000286 [Accessed: December, 2017].

Winch, G. (2010) Managing Construction Projects, Oxford: Blackwell Science.

Wuyts, S., Verhoef, P. C. and Prins, R. (2009) Partner Selection in B2B Information Service Markets. International Journal of Research in Marketing, Vol. 26, No. 1, pp. 41-51.

Yang, J. B. And Yang, C. C. (2010) Evaluating Schedule Delay Causes for Private Participating Public Construction Works Under the Build-Operate-Transfer Model, International Journal of Project Management, Vol. 28, No. 1, pp. 569-579.

Yiu, C.Y., Lo, S.M., Ng, S.T. and Ng, M.M.F. (2002) Contractor Selection for Small Building Works in Hong Kong, Structural Survey, Vol. 20, No. 4, pp. 129-135. 


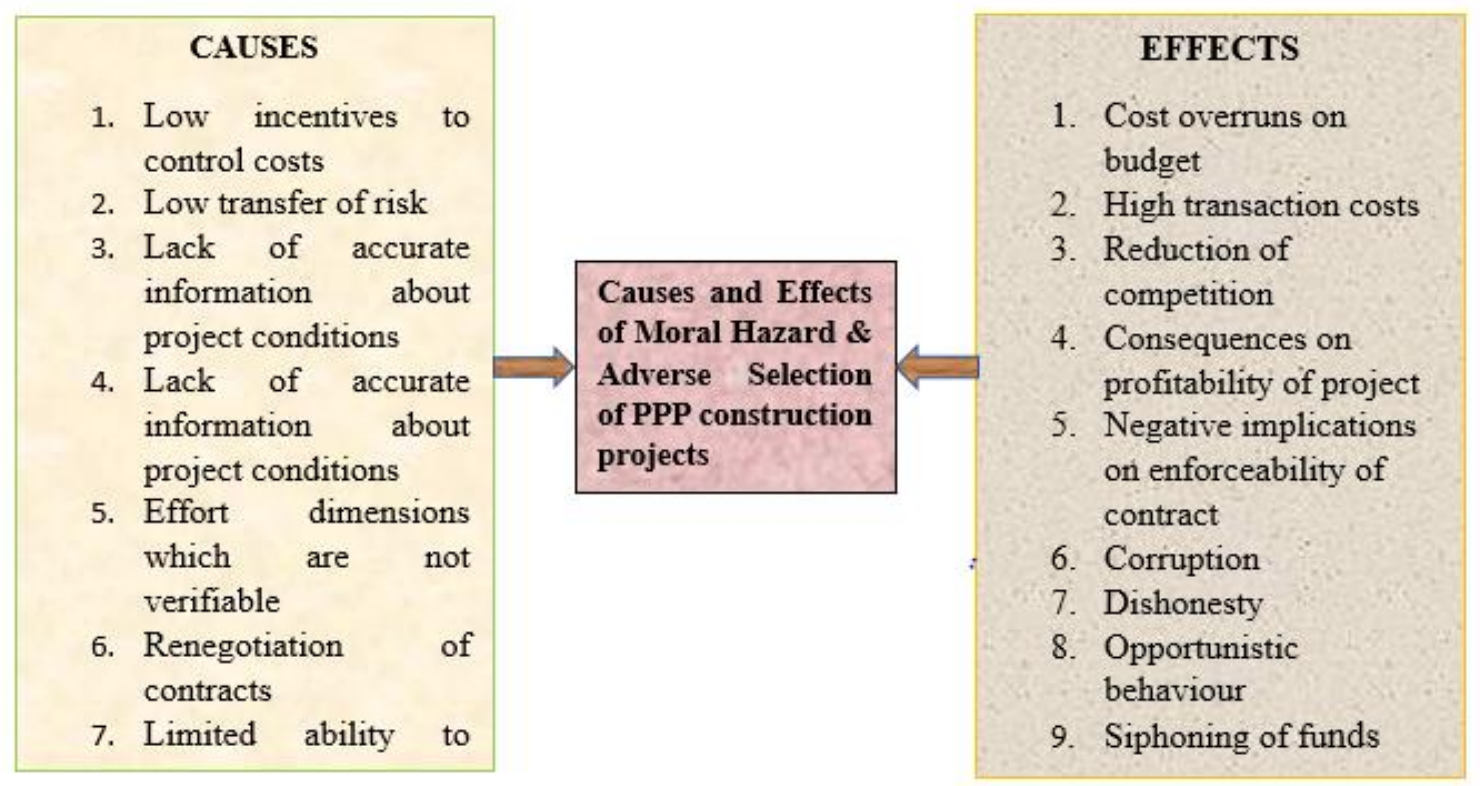

Figure I - Conceptual Framework for Causes and Effects of Moral Hazard and Adverse Selection of Public-Private-Partnership (PPP) Construction Projects 
Table I - Coding of Causes for SEM Analysis

\begin{tabular}{lc}
\hline \hline CAUSES & Code \\
\hline \hline Low incentives to control costs & $\mathrm{C} 1$ \\
\hline Wrong party chosen to execute project & $\mathrm{C} 2$ \\
\hline Low transfer of risk & $\mathrm{C} 3$ \\
\hline Lack of accurate information about project conditions & $\mathrm{C} 4$ \\
\hline Effort dimensions which are not verifiable & $\mathrm{C} 5$ \\
\hline Renegotiation of contracts & $\mathrm{C} 6$ \\
\hline Limited ability to commit to contractual obligations & $\mathrm{C} 7$ \\
\hline Inexperience & $\mathrm{C} 8$ \\
\hline \hline
\end{tabular}


Table II - Coding of Effects for SEM Analysis

\begin{tabular}{lc}
\hline \hline EFFECTS & Code \\
\hline \hline Cost overruns on budget & $\mathrm{A}$ \\
\hline High transaction costs & $\mathrm{B}$ \\
\hline Reduction of competition & $\mathrm{C}$ \\
\hline Consequences on profitability of project & $\mathrm{D}$ \\
\hline Negative implications on enforceability of contract & $\mathrm{E}$ \\
\hline Corruption & $\mathrm{F}$ \\
\hline Dishonesty & $\mathrm{G}$ \\
\hline Opportunistic behavior & $\mathrm{H}$ \\
\hline Siphoning of funds & $\mathrm{I}$ \\
\hline \hline
\end{tabular}


Table III (a) - Constructs and Final Items: Low Incentives to Control Costs

\begin{tabular}{lccccc}
\hline Variables & $\begin{array}{c}\text { Standardized } \\
\text { Coefficient }\end{array}$ & Std. Err & $\begin{array}{c}\text { C.R/ } \\
\text { Z-Value }\end{array}$ & $\begin{array}{c}\text { R- } \\
\text { Square }\end{array}$ & $\begin{array}{c}\text { Sig- } \\
\text { Value }\end{array}$ \\
\hline \hline C1B: High transaction costs & 0.463 & 0.079 & 5.880 & 0.214 & 0.000 \\
\hline $\begin{array}{l}\text { C1C: Reduction of } \\
\text { competition }\end{array}$ & 0.660 & 0.077 & 8.570 & 0.436 & 0.000 \\
\hline $\begin{array}{l}\text { C1D: Consequences on } \\
\text { profitability of project }\end{array}$ & 0.504 & 0.076 & 6.650 & 0.254 & 0.000 \\
\hline $\begin{array}{l}\text { C1H: Opportunistic } \\
\text { behaviour }\end{array}$ & 0.458 & 0.080 & 5.760 & 0.210 & 0.000 \\
\hline C1I: Siphoning of funds & 0.330 & 0.082 & 4.010 & 0.109 & 0.000 \\
\hline \hline
\end{tabular}

Table III (b) - Robust Fit Index: Low Incentives to Control Costs

\begin{tabular}{llcl}
\hline Fit Index & Cut-Off Value & Estimate & Remark \\
\hline \hline $\begin{array}{l}\text { S-B } \chi^{2} \\
\text { Df }\end{array}$ & & 9.481 & \\
Sig. Value & $\mathrm{x}>0.05$ & 5 & Good Fit \\
\hline CFI & $\begin{array}{l}\mathrm{x} \geq 0.90 \text { (Acceptable), } \\
\mathrm{x} \geq 0.95 \text { (Good Fit) }\end{array}$ & 0.091 & \\
\hline GFI & $\mathrm{x} \geq 0.90$ (Acceptable), & 0.951 & \multirow{2}{*}{ Good Fit } \\
\hline RMSEA & $\mathrm{x} \geq 0.95$ (Good Fit) & 0.983 & \multirow{2}{*}{ Good Fit } \\
\hline \hline
\end{tabular}


Table IV (a)- Constructs and Final Items: Wrong Party Chosen to Execute Project

\begin{tabular}{lccccc}
\hline \hline Variables & $\begin{array}{c}\text { Standardized } \\
\text { Coefficient }\end{array}$ & Std. Err & $\begin{array}{c}\text { C.R/ } \\
\text { Z-Value }\end{array}$ & $\begin{array}{c}\text { R- } \\
\text { Square }\end{array}$ & $\begin{array}{c}\text { Sig- } \\
\text { Value }\end{array}$ \\
\hline \hline C2A: Cost overruns on budget & 0.403 & 0.094 & 4.280 & 0.163 & 0.000 \\
\hline C2B: High transaction costs & 0.527 & 0.099 & 5.340 & 0.278 & 0.000 \\
\hline $\begin{array}{l}\text { C2C: Reduction of } \\
\text { competition }\end{array}$ & 0.434 & 0.094 & 4.620 & 0.189 & 0.000 \\
\hline $\begin{array}{l}\text { C2D: Consequences on } \\
\text { profitability of project }\end{array}$ & 0.311 & 0.102 & 3.050 & 0.097 & 0.002 \\
\hline $\begin{array}{l}\text { C2E: Negative implications on } \\
\text { enforceability of contract }\end{array}$ & 0.203 & 0.097 & 2.080 & 0.041 & 0.037 \\
\hline C2H: Opportunistic behaviour & 0.360 & 0.090 & 4.010 & 0.130 & 0.000 \\
\hline C2I: Siphoning of funds & 0.268 & 0.096 & 2.800 & 0.072 & 0.005 \\
\hline \hline
\end{tabular}

Table IV (b) - Robust Fit Index: Wrong Party Chosen to Execute Project

\begin{tabular}{llcl}
\hline \hline Fit Index & Cut-Off Value & Estimate & Remark \\
\hline \hline S-B $\chi^{2}$ & & 28.269 & \\
Df & & 14 & \\
Sig. Value & $x>0.05$ & 0.013 & \\
\hline CFI & $x \geq 0.90$ (Acceptable), & 0.787 & \\
\hline GFI & $x \geq 0.95$ (Good Fit) & 0.963 & \multirow{2}{*}{ Good Fit } \\
\hline RMSEA & $x \geq 0.90$ (Acceptable), & \multirow{2}{*}{ Acceptable } \\
\hline \hline
\end{tabular}


Table V (a) - Constructs and Final Items: Low Transfer of Risk

\begin{tabular}{lccccc}
\hline \hline Variables & $\begin{array}{c}\text { Standardized } \\
\text { Coefficient }\end{array}$ & Std. Err & $\begin{array}{c}\text { C.R/ } \\
\text { Z-Value }\end{array}$ & R-Square & $\begin{array}{c}\text { Sig- } \\
\text { Value }\end{array}$ \\
\hline \hline $\begin{array}{l}\text { C3A: Cost overruns on } \\
\text { budget }\end{array}$ & 0.387 & 0.074 & 5.230 & 0.150 & 0.000 \\
\hline C3B: High transaction costs & 0.518 & 0.071 & 7.310 & 0.268 & 0.000 \\
\hline $\begin{array}{l}\text { C3C: Reduction of } \\
\text { competition }\end{array}$ & 0.614 & 0.064 & 9.580 & 0.378 & 0.000 \\
\hline $\begin{array}{l}\text { C3D: Consequences on } \\
\text { profitability of project }\end{array}$ & 0.500 & 0.070 & 7.130 & 0.250 & 0.000 \\
\hline $\begin{array}{l}\text { C3E: Negative implications } \\
\text { on enforceability of contract }\end{array}$ & 0.646 & 0.065 & 9.940 & 0.417 & 0.000 \\
\hline C3G: Dishonesty & 0.382 & 0.074 & 5.170 & 0.146 & 0.000 \\
\hline \hline
\end{tabular}

Table V (b) - Robust Fit Index: Low Transfer of Risk

\begin{tabular}{|c|c|c|c|}
\hline Fit Index & Cut-Off Value & Estimate & Remark \\
\hline S-B $\chi^{2}$ & & 16.395 & \\
\hline Df & & 9 & Acceptable \\
\hline Sig & $x>0.05$ & 0.059 & \\
\hline CFI & $\begin{array}{l}x \geq 0.90 \text { (Acceptable) } \\
x \geq 0.95 \text { (Good Fit) }\end{array}$ & 0.951 & Good Fit \\
\hline GFI & $\begin{array}{l}x \geq 0.90 \text { (Acceptable) } \\
x \geq 0.95 \text { (Good Fit) }\end{array}$ & 0.974 & Good Fit \\
\hline RMSEA & $\begin{array}{l}x \leq 0.08(\text { Acceptable }) \\
x \leq 0.05(\text { Good Fit })\end{array}$ & 0.063 & Acceptable \\
\hline
\end{tabular}


Table VI (a) - Constructs and Final Items: Lack of Accurate Information about Project Condition

\begin{tabular}{lccccc}
\hline Variables & $\begin{array}{c}\text { Standardized } \\
\text { Coefficient }\end{array}$ & $\begin{array}{c}\text { Std. } \\
\text { Err }\end{array}$ & $\begin{array}{c}\text { C.R/ } \\
\text { Z-Value }\end{array}$ & $\begin{array}{c}\text { R- } \\
\text { Square }\end{array}$ & $\begin{array}{c}\text { Sig- } \\
\text { Value }\end{array}$ \\
\hline \hline C4C: Reduction of competition & 0.198 & 0.120 & 1.660 & 0.039 & 0.097 \\
\hline $\begin{array}{l}\text { C4E: Negative implications on } \\
\text { enforceability of contract }\end{array}$ & 0.403 & 0.122 & 3.300 & 0.162 & 0.001 \\
\hline C4G: Dishonesty & 0.794 & 0.230 & 3.450 & 0.630 & 0.001 \\
\hline C4H: Opportunistic behaviour & 0.229 & 0.088 & 2.590 & 0.052 & 0.010 \\
\hline C4I: Siphoning of funds & -0.011 & 0.085 & -0.120 & 0.000 & 0.901 \\
\hline \hline
\end{tabular}

Table VI (b) - Robust Fit Index: Lack of Accurate Information about Project Condition

\begin{tabular}{llcl}
\hline Fit Index & Cut-Off Value & Estimate & Remark \\
\hline \hline S-B $\chi^{2}$ & & 8.94 & \\
Df & & 5 & Good Fit \\
Sig & $x>0.05$ & 0.111 & \\
\hline CFI & $x \geq 0.90$ (Acceptable) & 0.885 & \\
\hline GFI & $x \geq 0.95$ (Good Fit) & 0.984 & Good Fit \\
\hline RMSEA & $x \geq 0.90$ (Acceptable), \\
& $x \geq 0.95$ (Good Fit) & \multirow{2}{*}{ Acceptable } \\
\hline \hline
\end{tabular}


Table VII (a) - Constructs and Final Items: Effort Dimensions which are not Verifiable

\begin{tabular}{lccccc}
\hline Variables & $\begin{array}{c}\text { Standardized } \\
\text { Coefficient }\end{array}$ & Std. Err & $\begin{array}{c}\text { C.R/ } \\
\text { Z-Value }\end{array}$ & R-Square & $\begin{array}{c}\text { Sig- } \\
\text { Value }\end{array}$ \\
\hline \hline C5A: Cost overruns on budget & 0.181 & 0.090 & 2.020 & 0.033 & 0.044 \\
\hline C5C: Reduction of competition & 0.391 & 0.098 & 4.000 & 0.153 & 0.000 \\
\hline $\begin{array}{l}\text { C5D: Consequences on } \\
\text { profitability of project }\end{array}$ & 0.817 & 0.159 & 5.150 & 0.668 & 0.000 \\
\hline $\begin{array}{l}\text { C5E: Negative implications on } \\
\text { enforceability of contract }\end{array}$ & 0.292 & 0.090 & 3.230 & 0.085 & 0.001 \\
\hline C5G: Dishonesty & -0.200 & 0.081 & -2.480 & 0.040 & 0.013 \\
\hline C5I: Siphoning of funds & 0.130 & 0.084 & 1.540 & 0.017 & 0.124 \\
\hline \hline
\end{tabular}

Table VII (b) - Robust Fit Index: Effort Dimensions which are not Verifiable

\begin{tabular}{llcl}
\hline \hline Fit Index & Cut-Off Value & Estimate & Remark \\
\hline \hline S-B $\chi^{2}$ & & 19.407 & \\
Df & & 9 & \\
Sig & $x>0.05$ & 0.022 & \\
\hline CFI & $x \geq 0.90$ (Acceptable), & 0.803 & \\
\hline GFI & $x \geq 0.95$ (Good Fit) & 0.97 & \multirow{2}{*}{ Good Fit } \\
\hline RMSEA & $x \geq 0.90$ (Acceptable) & & \\
\hline \hline
\end{tabular}


Table VIII (a) - Constructs and Final Items: Regeneration of Contracts

\begin{tabular}{lccccc}
\hline Variables & $\begin{array}{c}\text { Standardized } \\
\text { Coefficient }\end{array}$ & Std. Err & $\begin{array}{c}\text { C.R/ } \\
\text { Z-Value }\end{array}$ & $\begin{array}{c}\text { R- } \\
\text { Square }\end{array}$ & $\begin{array}{c}\text { Sig- } \\
\text { Value }\end{array}$ \\
\hline \hline $\begin{array}{l}\text { C6A: Cost overruns on } \\
\text { budget }\end{array}$ & 0.428 & 0.077 & 5.550 & 0.183 & 0.000 \\
\hline C6G: Dishonesty & 0.384 & 0.077 & 5.000 & 0.148 & 0.000 \\
\hline $\begin{array}{l}\text { C6H: Opportunistic } \\
\text { behaviour }\end{array}$ & 0.850 & 0.091 & 9.300 & 0.722 & 0.000 \\
\hline C6I: Siphoning of funds & 0.460 & 0.072 & 6.430 & 0.211 & 0.000 \\
\hline \hline
\end{tabular}

Table VIII (b) - Robust Fit Index: Regeneration of Contracts

\begin{tabular}{llcl}
\hline \hline Fit Index & Cut-Off Value & Estimate & Remark \\
\hline \hline $\begin{array}{l}\text { S-B } \chi^{2} \\
\text { df }\end{array}$ & & $\begin{array}{c}1.917 \\
2\end{array}$ & Good Fit \\
Sig & $x>0.05$ & 0.384 & \\
\hline CFI & $x \geq 0.90$ (Acceptable) \\
& $x \geq 0.95$ (Good Fit) & 1.000 & Good Fit \\
\hline GFI & $x \geq 0.90$ (Acceptable) \\
RMSEA & $x \geq 0.95$ (Good Fit) & 0.995 & Good Fit \\
\hline \hline
\end{tabular}


Table IX (a) - Constructs and Final Items: Limited Ability to Commit to Contractual Obligations

\begin{tabular}{lccccc}
\hline Variables & $\begin{array}{c}\text { Standardized } \\
\text { Coefficient }\end{array}$ & Std. Err & $\begin{array}{c}\text { C.R/ } \\
\text { Z-Value }\end{array}$ & $\begin{array}{c}\text { R- } \\
\text { Square }\end{array}$ & $\begin{array}{c}\text { Sig- } \\
\text { Value }\end{array}$ \\
\hline \hline C7B: High transaction costs & 0.195 & 0.105 & 1.850 & 0.038 & 0.064 \\
\hline $\begin{array}{l}\text { C7E: Negative implications on } \\
\text { enforceability of contract }\end{array}$ & 0.295 & 0.095 & 3.090 & 0.087 & 0.002 \\
\hline C7F: Corruption & 0.973 & 0.277 & 3.510 & 0.946 & 0.000 \\
\hline C7G: Dishonesty & 0.297 & 0.102 & 2.890 & 0.088 & 0.004 \\
\hline \hline
\end{tabular}

Table IX (b) - Robust Fit Index: Limited Ability to Commit to Contractual Obligations

\begin{tabular}{llcc}
\hline \hline Fit Index & Cut-Off Value & Estimate & Remark \\
\hline \hline S-B $\chi^{2}$ & & 4.780 & \\
Df & & 2.000 & \multirow{2}{*}{ Good Fit } \\
Sig & $\mathrm{x}>0.05$ & 0.092 & \\
\hline \multirow{2}{*}{ CFI } & $\mathrm{x} \geq 0.90$ (Acceptable), & 0.935 & \multirow{2}{*}{ Acceptable } \\
\hline \multirow{2}{*}{ GFI } & $\mathrm{x} \geq 0.95$ (Good Fit) & \multirow{2}{*}{0.989} & \multirow{2}{*}{ Good Fit } \\
\hline \multirow{2}{*}{ RMSEA } & $\mathrm{x} \geq 0.90$ (Acceptable), & \multirow{2}{*}{ Acceptable } \\
\hline \hline
\end{tabular}


Table X (a) - Constructs and Final Items: Inexperience

\begin{tabular}{lccccc}
\hline Variables & $\begin{array}{c}\text { Standardized } \\
\text { Coefficient }\end{array}$ & Std. Err & $\begin{array}{c}\text { C.R/ } \\
\text { Z-Value }\end{array}$ & $\begin{array}{c}\text { R- } \\
\text { Square }\end{array}$ & $\begin{array}{c}\text { Sig- } \\
\text { Value }\end{array}$ \\
\hline \hline C8A: Cost overruns on budget & 0.033 & 0.100 & 0.330 & 0.001 & 0.740 \\
\hline C8B: High transaction costs & 0.418 & 0.078 & 5.320 & 0.174 & 0.000 \\
\hline $\begin{array}{l}\text { C8C: Reduction of } \\
\text { competition }\end{array}$ & 0.579 & 0.074 & 7.790 & 0.335 & 0.000 \\
\hline $\begin{array}{l}\text { C8D: Consequences on } \\
\text { profitability of project }\end{array}$ & 0.598 & 0.073 & 8.220 & 0.357 & 0.000 \\
\hline C8F: Corruption & 0.434 & 0.080 & 5.440 & 0.188 & 0.000 \\
\hline C8G: Dishonesty & 0.450 & 0.077 & 5.810 & 0.202 & 0.000 \\
\hline C8I: Siphoning of funds & 0.278 & 0.082 & 3.410 & 0.077 & 0.001 \\
\hline \hline
\end{tabular}

Table X (b) - Robust Fit Index: Inexperience

\begin{tabular}{llcc}
\hline \hline Fit Index & Cut-Off Value & Estimate & Remark \\
\hline \hline S-B $\chi^{2}$ & & $\begin{array}{l}18.714 \\
14.000 \\
\text { df }\end{array}$ & \multirow{2}{*}{ Good Fit } \\
Sig & $x>0.05$ & 0.176 & \\
\hline \multirow{2}{*}{ CFI } & $x \geq 0.90$ (Acceptable), & \multirow{2}{*}{ Acceptable } \\
\hline \multirow{2}{*}{ GFI } & $x \geq 0.95$ (Good Fit) & \multirow{2}{*}{0.977} & \multirow{2}{*}{ Good Fit } \\
\hline \multirow{2}{*}{ RMSEA } & $\mathrm{x} \geq 0.90$ (Acceptable), & \multirow{2}{*}{ Good Fit } \\
\hline \hline
\end{tabular}


Table XI - Measurement Model: Relationship between Causes and Effects

\begin{tabular}{|c|c|c|c|c|c|}
\hline Variables & Standardized Coefficient & Std. Err & $\begin{array}{c}\text { C.R/ } \\
\text { Z-Value }\end{array}$ & R-Square & Sig-Value \\
\hline \multicolumn{6}{|c|}{ "Low Incentives to Control Costs } \\
\hline $\mathrm{C} 1 \mathrm{~B}$ & 0.463 & 0.079 & 5.880 & 0.214 & 0.000 \\
\hline $\mathrm{C} 1 \mathrm{C}$ & 0.660 & 0.077 & 8.570 & 0.436 & 0.000 \\
\hline C1D & 0.504 & 0.076 & 6.650 & 0.254 & 0.000 \\
\hline $\mathrm{C} 1 \mathrm{H}$ & 0.458 & 0.080 & 5.760 & 0.210 & 0.000 \\
\hline C1I & 0.330 & 0.082 & 4.010 & 0.109 & 0.000 \\
\hline \multicolumn{6}{|c|}{ Wrong Party Chosen to Execute Project } \\
\hline $\mathrm{C} 2 \mathrm{~A}$ & 0.403 & 0.094 & 4.280 & 0.163 & 0.000 \\
\hline $\mathrm{C} 2 \mathrm{~B}$ & 0.527 & 0.099 & 5.340 & 0.278 & 0.000 \\
\hline $\mathrm{C} 2 \mathrm{C}$ & 0.434 & 0.094 & 4.620 & 0.189 & 0.000 \\
\hline C2D & 0.311 & 0.102 & 3.050 & 0.097 & 0.002 \\
\hline $\mathrm{C} 2 \mathrm{E}$ & 0.203 & 0.097 & 2.080 & 0.041 & 0.037 \\
\hline $\mathrm{C} 2 \mathrm{H}$ & 0.360 & 0.090 & 4.010 & 0.130 & 0.000 \\
\hline C2I & 0.268 & 0.096 & 2.800 & 0.072 & 0.005 \\
\hline \multicolumn{6}{|c|}{ Low Risk Transfer } \\
\hline $\mathrm{C} 3 \mathrm{~A}$ & 0.387 & 0.074 & 5.230 & 0.150 & 0.000 \\
\hline C3B & 0.518 & 0.071 & 7.310 & 0.268 & 0.000 \\
\hline $\mathrm{C} 3 \mathrm{C}$ & 0.614 & 0.064 & 9.580 & 0.378 & 0.000 \\
\hline C3D & 0.500 & 0.070 & 7.130 & 0.250 & 0.000 \\
\hline C3E & 0.646 & 0.065 & 9.940 & 0.417 & 0.000 \\
\hline $\mathrm{C} 3 \mathrm{G}$ & 0.382 & 0.074 & 5.170 & 0.146 & 0.000 \\
\hline \multicolumn{6}{|c|}{ Lack of Accurate Information about Project Condition } \\
\hline $\mathrm{C} 4 \mathrm{C}$ & 0.198 & 0.120 & 1.660 & 0.039 & 0.097 \\
\hline $\mathrm{C} 4 \mathrm{E}$ & 0.403 & 0.122 & 3.300 & 0.162 & 0.001 \\
\hline $\mathrm{C} 4 \mathrm{G}$ & 0.794 & 0.230 & 3.450 & 0.630 & 0.001 \\
\hline $\mathrm{C} 4 \mathrm{H}$ & 0.229 & 0.088 & 2.590 & 0.052 & 0.010 \\
\hline C4I & -0.011 & 0.085 & -0.120 & 0.000 & 0.901 \\
\hline \multicolumn{6}{|c|}{ Effort Dimensions which are not Verifiable } \\
\hline C5A & 0.181 & 0.090 & 2.020 & 0.033 & 0.044 \\
\hline C5C & 0.391 & 0.098 & 4.000 & 0.153 & 0.000 \\
\hline C5D & 0.817 & 0.159 & 5.150 & 0.668 & 0.000 \\
\hline C5E & 0.292 & 0.090 & 3.230 & 0.085 & 0.001 \\
\hline C5G & -0.200 & 0.081 & -2.480 & 0.040 & 0.013 \\
\hline C5I & 0.130 & 0.084 & 1.540 & 0.017 & 0.124 \\
\hline
\end{tabular}




\begin{tabular}{|c|c|c|c|c|c|}
\hline \multicolumn{6}{|c|}{ Regeneration of Contracts } \\
\hline C6A & 0.428 & 0.077 & 5.550 & 0.183 & 0.000 \\
\hline C6G & 0.384 & 0.077 & 5.000 & 0.148 & 0.000 \\
\hline $\mathrm{C} 6 \mathrm{H}$ & 0.850 & 0.091 & 9.300 & 0.722 & 0.000 \\
\hline C6I & 0.460 & 0.072 & 6.430 & 0.211 & 0.000 \\
\hline \multicolumn{6}{|c|}{ Limited Ability to Commit to Contractual Obligations } \\
\hline $\mathrm{C} 7 \mathrm{~B}$ & 0.195 & 0.105 & 1.850 & 0.038 & 0.064 \\
\hline C7E & 0.295 & 0.095 & 3.090 & 0.087 & 0.002 \\
\hline $\mathrm{C} 7 \mathrm{~F}$ & 0.973 & 0.277 & 3.510 & 0.946 & 0.000 \\
\hline $\mathrm{C} 7 \mathrm{G}$ & 0.297 & 0.102 & 2.890 & 0.088 & 0.004 \\
\hline \multicolumn{6}{|c|}{ Inexperience } \\
\hline $\mathrm{C} 8 \mathrm{~A}$ & 0.033 & 0.100 & 0.330 & 0.001 & 0.740 \\
\hline $\mathrm{C} 8 \mathrm{~B}$ & 0.418 & 0.078 & 5.320 & 0.174 & 0.000 \\
\hline $\mathrm{C} 8 \mathrm{C}$ & 0.579 & 0.074 & 7.790 & 0.335 & 0.000 \\
\hline C8D & 0.598 & 0.073 & 8.220 & 0.357 & 0.000 \\
\hline $\mathrm{C} 8 \mathrm{~F}$ & 0.434 & 0.080 & 5.440 & 0.188 & 0.000 \\
\hline $\mathrm{C} 8 \mathrm{G}$ & 0.450 & 0.077 & 5.810 & 0.202 & 0.000 \\
\hline C8I & 0.278 & 0.082 & 3.410 & 0.077 & 0.001 \\
\hline
\end{tabular}


Figure II - Structural Equation Model

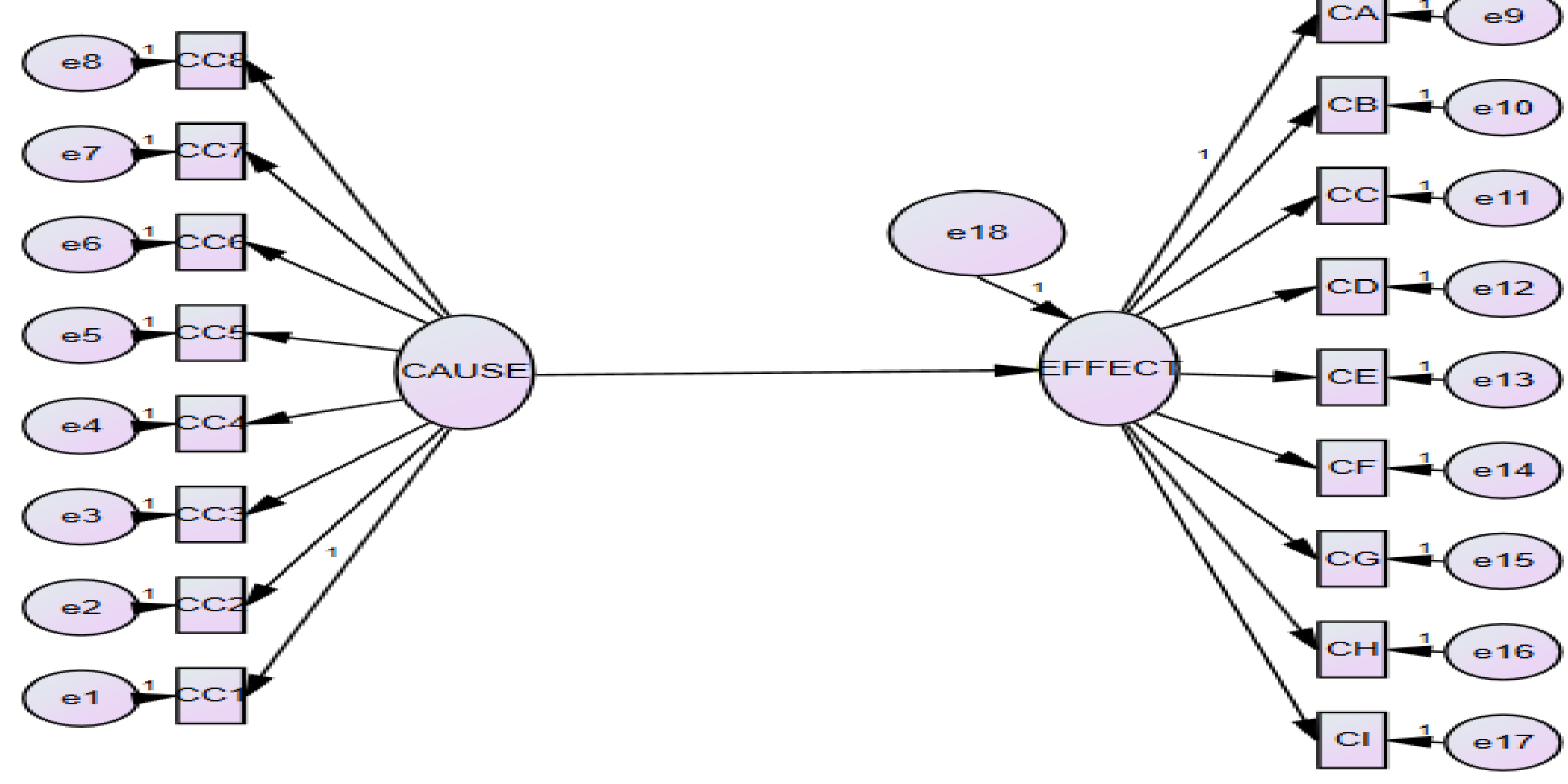

